\title{
Clinical Manifestations of Brucellosis in Domestic Animals and Humans
}

\author{
Jane Megid ${ }^{*}, 1$ Luis Antonio Mathias ${ }^{2}$ and Carlos A. Robles ${ }^{3}$ \\ ${ }^{1}$ UNESP - Universidade Estadual Paulista - School of Veterinary Medicine and Animal Science- Department of \\ Veterinary Hygiene and Public Health, Botucatu-SP, Brazil \\ ${ }^{2}$ UNESP - Universidade Estadual Paulista - School of Veterinary Medicine and, Agrarian Science- Department of \\ Veterinary Hygiene and Animal Reproduction-SP, Brazil \\ ${ }^{3}$ National Institute for Agricultural Technology (INTA) CC: 277 (8400) Bariloche, Argentina
}

\begin{abstract}
Brucellosis in domestic animals is a chronic disease that is characterized mainly by reproductive signs in cattle, buffaloes, pigs, sheep, goats and dogs. In females the disease is characterized by abortion, placenta retention, vaginal secretions, low fertility rate and also embryonic and neonatal death. In males, regular findings include epididymitis, orchitis, uni- or bilateral testicular atrophy, sperm abnormalities and infertility. Lymphadenopathy, hepatopathy, splenomegaly, uveitis and discospondylitis may also be observed in dogs. In horses, the typical clinical sign is characterized by a granulomatous supraspinous or supra-atlantal bursa lesion. Infected animals can also be asymptomatic. Infected symptomatic or asymptomatic animals represent an important source of infection to other animals and humans. Brucellosis in humans can cause undulant fever, malaise, insomnia, anorexia, headache, arthralgia, constipation, sexual impotence, nervousness and depression. For all species the presentation of clinical signs are only suggestive of disease infection and thus must be differentiated from other diseases.
\end{abstract}

Keywords: Brucellosis, clinical signs, review, cattle, buffaloes, dogs, sheep, goats, human.

\section{INTRODUCTION}

Brucellosis is one of the most important infectious causes of reproductive disorders in domestic animals. The disease is also called contagious abortion, infectious abortion, and epizootic abortion. In horses it received the name of "fistulous withers" and "poll evil". In cattle, this illness is called Bang in tribute to the Danish veterinarian, who was the pioneer in the study of this disease in this species. This illness in humans received the name of Malta fever, Mediterranean fever and Gibraltar fever according to the region in which the illness was first described. It is also known as undulating fever due to its oscillating temperature presented by infected persons.

Clinical signs vary according to the animal species that is being infected and the infecting Brucella species.

\section{BRUCELLOSIS IN CATTLE}

Bovine brucellosis is usually caused by $B$. abortus which has seven different biovars, named 1, 2, 3, 4, 5, 6 and 9. Biovar 1 is the most important and widespread B. abortus biovar. Among 530 B. abortus samples isolated from humans and animals in Latin America from 1968 to 1991, $399(75.3 \%)$ were biovar 1 and most of them were isolated from cattle [1]. Natural infection with other Brucella species is rare. In areas where B. melitensis infection is enzootic in small ruminants, it is rarely seen abortion in cattle even

*Address correspondence to this author at the UNESP - Universidade Estadual, Paulista- Faculdade de Medicina Veterinária e Zootecnia Departamento de Higiene Veterinária e Saúde Pública - 18618-000Botucatu-SP, Brazil; Tel 00551438116270; Fax: 00551438116075;

E-mail: jane@fmvz.unesp.br though some infected animals may become carriers and excrete the bacteria in the milk [2]. In France, Verger et al. [3] reported that $15 \%$ of the strains isolated from cattle had all the features of B. melitensis. Dafni et al. [4] described foci of $B$. melitensis infection in cattle in Israel, but the occurrence of abortion was not confirmed. B. suis infection in cattle is self-limiting and thus it is not sustained [5].

Sexually mature females are more susceptible to $B$. abortus infection than bulls [2]. This susceptibility increases during pregnancy, and animals get more susceptible with the advance of pregnancy [6]. B. abortus infection in calf is selflimiting [7].

The period of incubation varies considerably and it is mainly influenced by gestation, exposure dose, age, and vaccination [2]. The length of the incubation period is inversely proportional to the stage of gestation at the time of exposure. Bang [8] observed an abortion in a three-month pregnant heifer 56 days after feeding her with the cotyledons from an aborting cow. Other experimental studies have shown incubation periods varying from 53 to 251 days [9].

The major clinical sign in pregnant females is abortion in bovine and buffalo cows (Fig. 1). Abortion usually occurs from the $5^{\text {th }}$ to the $8^{\text {th }}$ month of gestation. The occurrence of abortion is related to some factors, such as the stage of pregnancy, the number of infecting organisms and the animal resistance [2]. Fitch et al. [10] examined 41 gravid uteri and B. abortus was not isolated from uteri before 4.5 months of pregnancy; the organism, however, was isolated from 13 out of 29 uteri that were in gestation later than 4.5 months. Bang [8] observed that infected pregnant females usually abort only once, and concluded that infected cows acquire immunity. Alternatively to abortion, premature, 
stillborn or weak calves may occur. Abortion is often followed by placental retention and metritis, which may cause permanent or transient infertility [11].

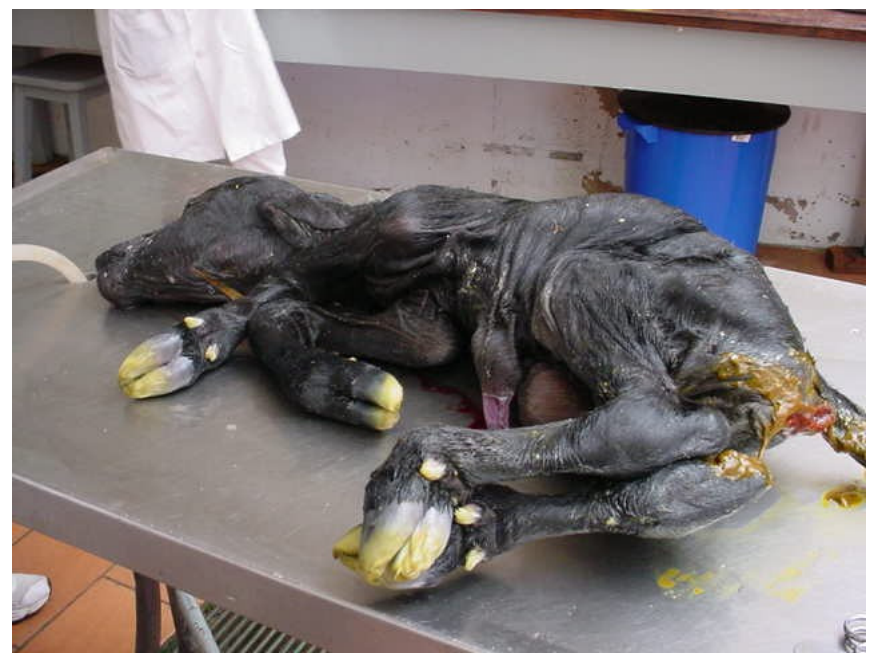

Fig. (1). Bubalin aborted fetus due to Brucella abortus biovar 1 infection.

Brucellosis does not usually result gross organic lesions $[12,13]$, but sometimes a mild interstitial inflammatory reaction in the mammary gland may be observed [14], which is associated with elimination of bacteria in the milk. Mammary gland macrophages may provide the intracellular environment for the persistence of $B$. abortus in the mammary gland of chronically infected cows [15].

Despite being susceptible to the infection [16], no clinical signs have been observed in infected heifers at prepubescent stage. Edgington and Donham [17] reported that 15 heifers experimentally infected with $B$. abortus before breeding failed to abort during the subsequent pregnancy, but there are evidences that heifers infected before adulthood may abort and contribute to maintain the infection in the herd [18].

The pathogenic action of $B$. abortus infection in bulls has long been established. Schroeder and Cotton [18] isolated the causal agent during the autopsy of a bull from an epididymis abscess, and Buck et al. [19] isolated it from bulls with seminal vesiculitis and/or orchitis. Infection of the reproductive tract may leads to orchitis, epididymitis, ampullitis and seminal vesiculitis. Orchitis is occasionally manifested, and when it occurs it is usually unilateral, but both testicles may be affected. Scattered foci of necrosis coalesce to produce total testicular necrosis (Fig. 2) [20]. Atrophy of testicle may also occur [21, 22]. Plant et al. [22] considered that the syndrome involving seminal vesicles and ampoule is apparently more common than the one involving the testicles and epididymides.

The incubation period of brucellosis in bulls has not been clearly determined. Lambert et al. [23] observed orchitis due to strain 19 of $B$. abortus ten days after vaccination, and Danks [24] reported orchitis due to the same strain seven months after vaccination. Lubbehusen and Fitch [25] reported no clinical changes in three young bulls challenged with $B$. abortus on three occasions over a six-month period. Plant et al. [22] observed, in one bull, that the time from infection to the development of orchitis was at least 122 days. Occasionally, hygromas [26] and arthritis [27] are observed.

Brucellosis may result in fetal pneumonia, and to the naked eye the only recognizable lesion is a consolidation of the lungs associated with a grayish mottling in a certain number of fetuses [28]. Nevertheless not all the brucellosis aborted fetuses have pneumonia, and lung lesions are not specific enough to enable us to incriminate $B$. abortus as the cause of abortion [29]. Others gross lesions are also frequently described in aborted fetuses. Xavier et al. [14] observed that cows that were experimentally infected with $B$. abortus presented either weak newborn calves or aborted fetuses with mild peritonitis and abdominal organs covered with a small amount of fibrinous exudate, and such exudate was also found in their pericardium.

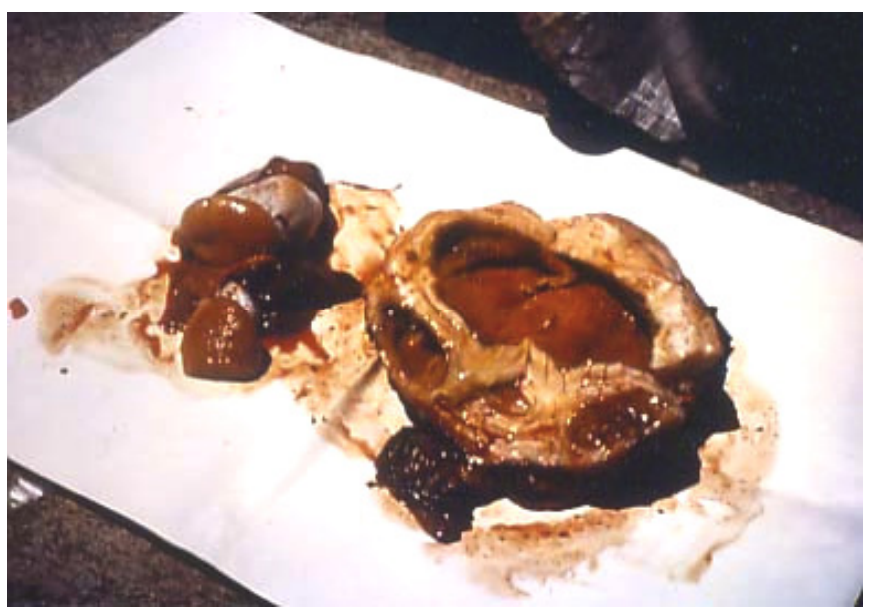

Fig. (2). Necrosis in the testicle (right) of a Brucella abortus infected bull with unilateral orchitis.

\section{BRUCELLOSIS IN PIGS}

B. suis is the only species that causes systemic infection leading to reproductive problems in the swine. Swine can be infected by other Brucella species but the infection is invariably self-limiting [30].

Clinical signs of B. suis infection in the swine vary considerably, depending on the animal age, previous exposure, and the organ involved [31]. Manifestations of swine brucellosis are abortion, birth of weak piglets, infertility, orchitis, epididymitis, spondylitis of especially the lumbar and sacral regions, arthritis, paralysis of hindlimbs, and lameness, but many infected herds may have no signs. There is no pyrexia, and death is rare [30]. Abscesses of different sizes frequently occur in organs and tissues [11].

The rate of abortion is higher in sows or gilts exposed to $B$. suis via the genital tract at the time of breeding. Abortions may occur at any time and are influenced more by the time of exposure to the $B$. suis rather than by the stage of gestation [30]. Abortions have been observed as early as 17 days following natural insemination by boars disseminating $B$. suis in the semen. Early abortions are usually unnoticed by the owner, and the only evidence of infection is that the sow displays signs of estrus 30 to 45 days after mating. Little or no vaginal discharge is observed in early abortions. Abortions that occur during mid or late stages of gestation are usually associated with females that acquire infection after 35 to 40 days of pregnancy [31]. Affected sows rarely 
have a second abortion, and females infected before sexual maturity hardly ever abort [11]. A clinically apparent abnormal vaginal exudate is seldom observed in sows that have uterine infection [30].

Some infected boars do not develop a localized genital infection. However, boars that do develop genital infection seldom recover from it. Infertility and lack of sexual activity may occur in infected boars and is frequently associated with testicular involvement (Fig. 3). More commonly, boars have infections in their accessory genital glands; however this does not necessarily reduce fertility [30]. Infection of the genital organs lasts for a shorter period of time in the female than in the male [11].

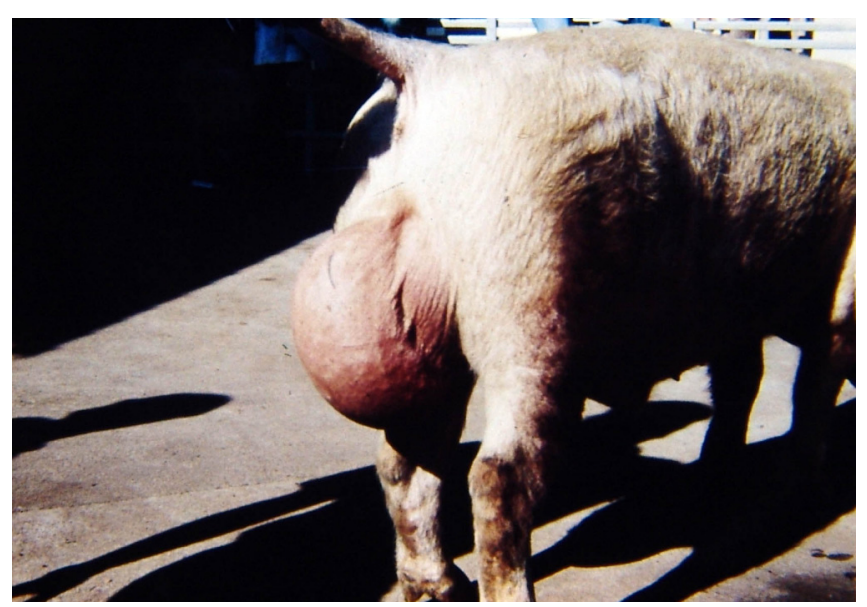

Fig. (3). Boar. Unilateral testicular enlargement due to Brucella suis infection. (Photograph from Correa, WM).

The disease is more common in adults. Clinical evidence of brucellosis in suckling and weaning piglets is usually absent. Clinical manifestations of arthritis and lameness or spondylitis associated with paralysis of hindlimbs are occasionally observed in any age of swines [30].

\section{BRUCELLOSIS IN SHEEP AND GOATS}

Brucellosis in sheep and goats are mainly caused by $B$. melitensis and B. ovis. However, other types of Brucella can infect sheep and goats. $B$. abortus was isolated from eight sheep and from their offspring over a period of 40 months [32] and B. suis was isolated from the semen of a ram [33].

Brucella infection produces a chronic disease on sexually mature animals, being the genital tract the main target of the bacteria. B. melitensis affects both species, being abortion in females the main clinical sign, whereas $B$. ovis affects only sheep and it is the cause of contagious epididymitis of rams $[34,35]$. The effect of the disease at flock level is characterized by a general decrease in flock fertility, an increase in lamb/kid mortality with a low weaning percentage, a decrease on milk production and an increased culling of males due to chronic lesion on reproductive organs [36-39].

\section{BRUCELLOSIS IN SHEEP AND GOATS DUE TO BRUCELLA MELITENSIS}

The goat is considered the primary host for B. melitensis, which seems to be the case in Latin America and Malta, where sheep are not significantly infected, meanwhile in the
Mediterranean countries, sheep and goats are equally infected $[35,37,38]$.

Since $B$. melitensis is the least species-specific Brucellae, it can be isolated from a wide range of domestic and wild animals and is the cause of Malta fever, one of the most important zoonotic diseases. Man is infected following both contact with infected animals or the consumption of infected raw milk, and non pasteurized dairy products like the soft goat or sheep cheeses [11, 35, 39, 40, 41].

The disease is widespread all over the world, being endemic in some European countries particularly in the Mediterranean region, Latin America except for Brazil and Chile, Center and West Asia, Middle East and sporadically other nations from Africa, and India. However, North America, South East Asia, Australia and New Zealand are believed to be free $[37,42]$.

B. melitensis preferentially locates in the reproductive tract and lymphatic ganglia of females and males. However, it can colonize the central nervous system, bone marrow, mammary glands, bones, renal cortex and synovial membranes, producing focal granulomatous lesions $[43,44]$.

The infection of sheep and goats occur mainly through the nasopharynx route. $B$. melitensis can also be transmitted from the mother to the lamb/kid "in uterus" or via the colostrum or milk [45]. Via lymphatic vessels the bacteria reach the regional lymph nodes and if local defenses fail in controlling the infection, following a bacteremic phase, the uterus will become infected. In a more advanced phase $B$. melitensis can colonize the udder of lactating goat and sheep females, resulting in acute mastitis with the production of clotted and watery milk and reducing milk yields [34, 43].

The main clinical signs of $B$. melitensis infection in the female are abortion in the last 2 months of gestation, placenta retention, and giving birth to weak offspring, who usually die in the peripartum. The placenta of an aborted female can show grey necrotic cotyledons and edema [46, 47]. Animals generally abort only once. It has been reported that abortion in female goats is produced between 3 and 4 weeks after being experimentally infected with high doses of $B$ melitensis. However, in sheep the abortion may occur between 4 to 12 weeks after being experimentally infected, and it seems that ewes are more resistant to abortion [37].

Infected females that have aborted will shed large numbers of Brucella to the environment, contaminating pastures, soil, and water. Shedding of Brucella through the vaginal fluid can be extended to 2 or 3 months after the abortion or parturition in goats, whereas in sheep it extends to about 3-4 weeks. In future parturition, the infected females, despite having a normal delivery, will continue shedding bacteria through the placenta, vaginal fluids and milk $[35,37]$.

Aborted fetuses can be in different development stages and have a normal aspect. In many cases it can be found bronchopneumonia, hemorrhagic fluid in the thoracic cavity, and enlarged lymph nodes, liver and spleen [37].

In sheep and goat males, the infection can be located in testis, epididymis, seminal vesicle and ampulla of deferent ducts, producing inflammation of genital organs. In the acute phase, it can be detected orchitis with inflammation of tunica 
vaginalis, and the scrotal sac can be distended by an either hemorrhagic or fibrino-purulent exudate. In a chronic stage, hygromas and joints' inflammation can be observed in male goats. The main output of the disease in males is semen of bad quality and a consequent fertility loss [38, 43, 44].

\section{BRUCELLOSIS IN SHEEP DUE TO BRUCELLA OVIS}

Brucella ovis is responsible for a disease in rams known as Contagious Epididymitis. When ewes become infected, abortion can occur as well as an increase in neonatal lamb mortality, but this is less frequent than in $B$. melitensis infection $[48,49]$. Ovine brucellosis due to B. ovis occurs worldwide affecting most of the countries where sheep is raised [50-59].

Although the initial clinical signs on rams are often unnoticed, pyrexia, lassitude and increased respiratory rate may occur associated with swollen testis and epididymis, pain and accumulation of exudate in the scrotal sac. Palpable epididymitis can appear between 15 to 45 days after experimental conjunctival inoculation [60-61].

In the chronic stage of the disease the epididymis can be increased in size up to four or fivefold (Fig. 4). At palpation the affected epididymis is firm, even hard with an irregular contour. There may be adhesions between the epididymis, the parietal tunica vaginalis and the testes [49, 60, 62]. It is necessary to have in mind that some infected rams showing palpable lesions at one examination may be clinically normal a few weeks later [63] and that not all the B. ovis infected rams are going to develop lesions in their external genital organs $[64,65]$. In a study carried out on Corriedale rams it could be observed that only $22(28 \%)$ out of 78 infected rams showed evident lesions in epididymis [66].

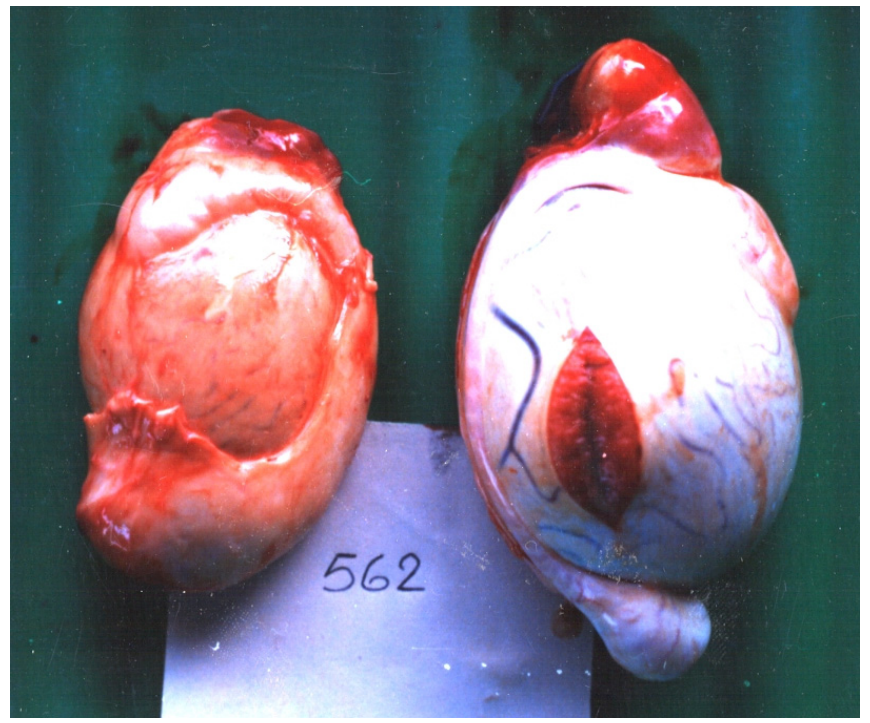

Fig. (4). Epididymitis in rams due to Brucella ovis infection. Notice the increase in size of the right epididymis.

Even though the epididymis may be totally affected, the tail of the epididymis is the most common output record at clinical examination. Robles et al. [67], examining 75 infected rams with lesions, reported that $70 \%$ had the tail of the epididymis affected, $14 \%$ the head, body and tail, $7 \%$ the body and tail, $4 \%$ body, $4 \%$ the head and body and $1 \%$ only the head. Affected rams have normal libido. However, semen quality is variable. Spermatozoa concentration and motility are often reduced, with morphological defects on the tails and detached heads [68]. Neutrophils are also commonly present $[58,59]$.

Clinically, the disease can be presumptively diagnosed in the ram by the palpation of external genital organs. Both testicles and epididymides are palpated simultaneously, comparing their size, shape, consistency, and symmetry [40, 69, 70]. Clinical signs and lesions described cannot be regarded as decisive since there are organisms other than $B$. ovis, including Actinobacillus seminis, Histophilus ovis, Corynebacterium spp., Escherichia coli, Pasteurella spp., etc., that also produce palpable epididymitis and orchitis [7173]. Therefore, other techniques, such as bacteriology and serology, need to be used to accurately diagnose the disease.

\section{BRUCELLOSIS IN HORSES}

The infection is caused by $B$. abortus and occasionally $B$. suis. The disease is acquired through contact with infected cattle or swine, ingestion of contaminated food or water and via penetration of the skin or mucous membrane. Brucellosis in horses can either remain asymptomatic [74] or it can be associated with clinical disease.

Experimental infection with $B$. abortus in horses induced only mild pyrexia. However, granulomatous lesions were observed in lung, liver, testes and metatarsophalangeal synovial membranes. The mares bred normally without abortion or other signs $[75,76]$. The disease is mainly recognized as an inflammation of the supraspinous and supra-atlantal bursa. These syndromes are known as "fistulous withers" and "poll evil" respectively. The bursal sac becomes distended by a clear, viscous, straw-colored exudate and develops a thickened wall. It can rupture, leading to a secondary point of infection (Fig. 5).

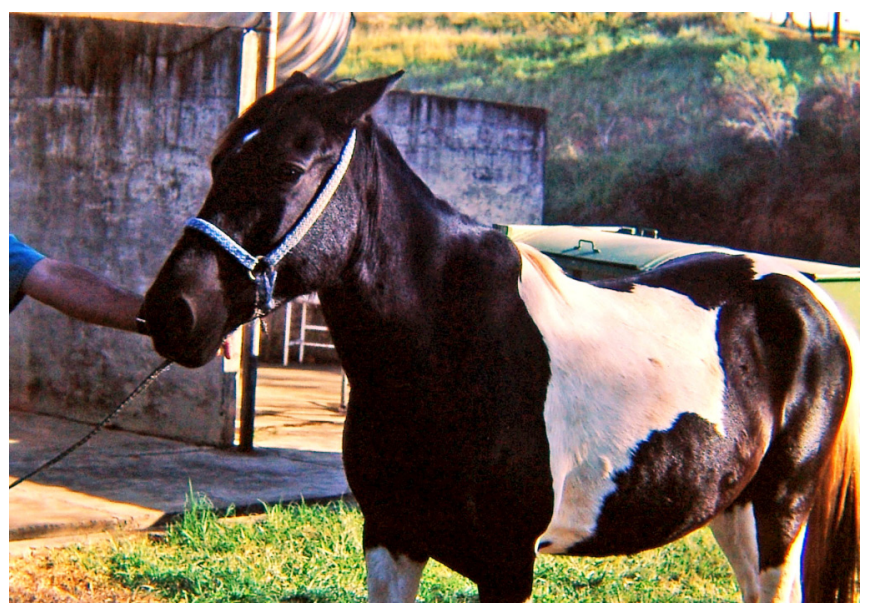

Fig. (5). "Fistulous withers" due to B. abortus infection. Left scapular region.

Not all cases of poll evil and fistulous withers are associated with Brucella; other bacteria such as Streptococcus zooepidemicus may be involved. Brucellaassociated abortions are rare in horses. Other clinical signs reported in horses due $B$. abortus infection are arthritis, intermittent lameness, lethargy and swelling of carpal joint [77-79]. 


\section{BRUCELLOSIS IN DOGS}

Brucella canis infection is one of the main infectious causes of reproductive disorders in wild and domestic dogs. The greatest prevalence rates probably occur among breeding dogs in commercial kennels [80] where significant reproductive losses can be seen. Up to $75 \%$ fewer puppies may be weaned from affected kennels according the hygienic and sanitary conditions $[80,81]$.

Clinical signs vary from asymptomatic to mild, despite an ongoing systemic infection. Morbidity is high but mortality is low. Bacteremia develops within two to three weeks after infection; the incubation period to clinical reproductive signs is variable [82].

The classic sign of canine brucellosis is late abortion, which can occur between 30-57 days of gestation, being more common from 45 to 55 days of gestation in about $75 \%$ of the cases. Abortions are followed by mucoid, serosanguineous, brownish or gray vaginal discharge that persists for up to six weeks $[82,83]$. Brucellosis does not change the presentation of estrus and breeding [83]. The infected female can produce consecutive abortions and present litters of sick-born pups that die a few hours to more than one month after delivery. Birth of apparently normal offspring who develop the disease later can occur [82-87]. Abortions, premature litters and conception failures are observed in infected kennels [81, 88].

Resorption or early embryonic death within 2 to 3 weeks after breeding can also occur [82, 83]. The female is considered infertile since no outward signs of fetal death were seen. Pups are lost as early as 20 days or are carried nearly to term. Infected bitches may deliver a normal litter the next pregnancy or give birth to living, partly autolyzed, stillborn and normal pups that die within hours. The surviving pups are bacteremic for a minimum of several months [83], other congenitally infected pups can be born normal and later develop brucellosis. Some pups have transient fever, leukocytosis or seizures as manifestations of systemic infection. The bitch can abort two to three litters consecutively, continue to be bred and have a normal litter later [83]. Clinical signs can occur during subsequent pregnancies in some dogs but not in all of them [82].

B. canis targets androgen-dependent organs in the infected dog. The main clinical manifestations in males are severe epididymitis, orchitis and prostatitis. Epididymitis usually begins 5 weeks after infection. Acute onset of inflammation with pain and swelling enables the physical examination detection of orchitis and epididymitis. During the acute phase, the epididymis increases in size, accompanied by pain and presence of serosanguineous fluid in the tunica. Scrotal dermatitis develops from a constant licking by the male leading to edema and dermatitis which usually presents secondary contamination by non-hemolytic staphylococci $[83,87]$.

History of failure to achieve intromission from pain, unwillingness to ejaculate or successful internal ties without pregnancy is reported by the owners $[66,83]$. Teratospermia with spermatozoa showing acrosome deformities, protoplasmatic droplets and midpiece defects are found. Other sperm abnormalities, such as dag-like defect, head defects and head-to-head binding sperm, are observed at 16 and 18-27 weeks after infection. Inflammatory cells composed of macrophages with phagocytized sperm cells surrounded by masses of neutrophils are observed later. In the chronic phase, sperm absence or reduced number of immature sperms, as well as a decrease in size and hardness of testicles can be observed. Not only that, but unilateral or bilateral atrophy and even complete sterility are found and they are associated with the autoimmune antisperm antibodies. It can also be seen reluctance to breed and/or loss of libido due to the painful experience [82, 83, 87]. B. canis persists in prostate gland and epididymis of infected males for several months, being disseminated by seminal fluid and urine [82].

In pre-pubescent males and females, bacteremia is frequent and the main clinical manifestation is generalized lymphadenopathy. The retropharyngeal lymph nodes may enlarge after oral infection and the superficial inguinal and external iliac nodes may do the same after vaginal infection $[80,87]$. Besides lymph nodes, the spleen and liver may become enlarged. The granulomatous reaction makes the spleen firm and nodular [80].

Non-specific reported signs are: poor hair coat, listlessness, fatigue, lethargy, exercise intolerance, weight loss, lameness, back pain, generalized lymph nodes enlargement, loss of libido, premature aging and behavioral changes $[82,83]$. Clinical signs are not pathognomonic for canine brucellosis but it should be a primary consideration in dogs with reproductive failure or infertility [83-87].

Other clinical signs like discospondylitis, meningitis, focal non-suppurative encephalitis, osteomyelitis, uveitis (Fig. 6) and abscesses in various internal organs [80, 89-91] are observed in infected dogs influenced by the bacteremia [80]. Discospondylitis is accompanied by acute pain in the vertebral column, lameness, paresis, ataxia and compression of the medulla [83, 87, 92]. Chronic or recurrent uveitis in the absence of systemic disease in infected dogs were reported by Ledbetter et al. [93]; the clinical ophthalmological abnormalities were unilateral and included mild-to-moderate anterior uveitis, iris hyper pigmentation, marked vitreal infiltrates, and multifocal chorioretinitis.

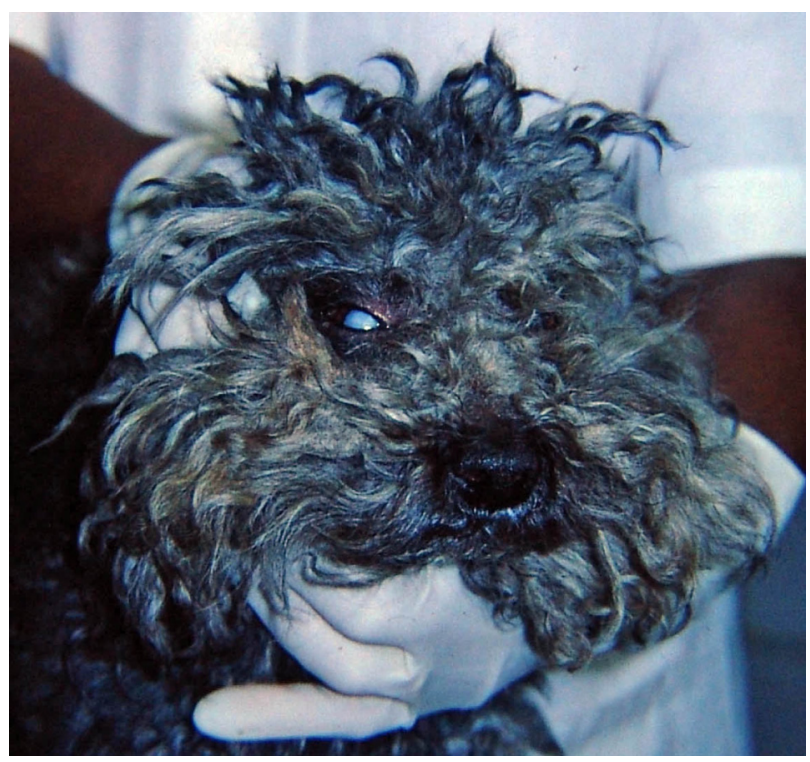

Fig. (6). Uveitis in a dog due to Brucella canis infection. 
Clinical signs are not pathognomonic, and can result from causes other than B. canis infection. Wanke et al. [94] observed abortion, infertility, perinatal mortality, discospondylitis, orchitis, epididymitis, uveitis, prostatitis in similar distribution among serologically negative and positive dogs, demonstrating the need of laboratorial diagnosis confirmation.

Clinical signs of B. abortus in dogs vary from mild fever to orchitis and testicular atrophy with shedding of organisms in urine [95-97]. Dogs experimentally infected with B. suis were reported afebrile and asymptomatic without gross lesions [98], but in natural conditions hindlimb weakness, large and firm epididymitis was observed associated to oligospermia and increased number of neutrophils in semen [99] similar to what was observed in B. canis infection.

Dogs with brucellosis may recover spontaneously as soon as one year after infection, but recovery is more common after 2 to 3 years after it, and some dogs remain chronically infected for at least five years [80].

\section{BRUCELLOSIS IN HUMANS}

B. abortus, B. melitensis, B. suis, B. canis, and marine mammal Brucella species are human pathogens. In humans, brucellosis can be a serious, debilitating and sometimes chronic disease that may affect a variety of organs. Most cases are caused by occupational exposure to infected animals or the ingestion of unpasteurized dairy products [80]. The incubation period is $1-3$ weeks but can be extended to several months. B. melitensis is the most important cause of human brucellosis worldwide [1,100], and it is associated with acute infection $(<2$ months) whereas the infection with other Brucella species are usually subacute (2-12 months) or chronic (>1 year) [100]. In countries where B. melitensis was not demonstrated, $B$. suis was more frequently isolated [1]. The most common signs of brucellosis are undulant fever in which the temperature can vary from $37^{\circ} \mathrm{C}$ in the morning to $40^{\circ} \mathrm{C}$ in the afternoon; night sweats with peculiar odor, chills and weakness. Malaise, insomnia, anorexia, headache, arthralgia, constipation, sexual impotence, nervousness and depression are also common. Fever was observed in $77.8 \%$ of infected patients, followed by joint pain (21\%), low backache (14\%) and several other symptoms in lower proportion [100].

Complications and involvement of internal organs can be diverse, depending on the site of infection, and include encephalitis, meningitis, spondylitis, arthritis, endocarditis, orchitis, and prostatitis [11]. Although unusual, spontaneous abortions have been seen in pregnant women infected with Brucella in early stages. Brucella endocarditis is a rare severe complication most commonly associated with $B$. melitensis and is responsible for at least $80 \%$ of deaths due to brucellosis $[100,101]$. Splenomegaly $(17.2 \%)$, hepatomegaly $(10.1 \%)$ and hepatosplenomegaly $(15.1 \%)$ were observed associated to clinical signs [100].

Neurological complications can occur during the onset of illness, convalescence period or even some months after recovery from an acute infection. Meningitis, encephalitis, meningoencephalitis, brain abscess, chorea, facial palsy, meningomyeloencephalo-spondylosis and ischemic attach have been reported [102, 103]. Brucella meningitis in infants was correlated to human breast milk transmission [103] and neurobrucellosis and intracerebral granulomas were reported in two patients infected with marine strains of Brucella [104]. Unusual manifestations of brucellosis as liver abscesses, pancytopenia, and acute pancreatitis were reported as caused by $B$. melitensis infection $[105,106]$.

B. canis infections have been reported in humans presenting recurrent fever, granulomatous hepatitis, splenomegaly [107], prolonged febrile illness [108], weakness, liver and spleen enlargement, submaxillary adenopathy [108], and attention must be taken to serological diagnostic results once there is no cross reaction between $B$. canis and smooth strains normally used in diagnostic tests for human diagnosis.

\section{CONCLUDING REMARKS}

Brucellosis in animals and humans is worldwide distributed and being considered one of the most important zoonosis. It is a chronic disease and can develop several clinical forms, presenting from reproductive to systemic clinical signs and sometimes being asymptomatic. Affected symptomatic or asymptomatic animals represent important source of infection eliminating the agent through secretions and excretions. Humans are affected by contact with infected animals or through the ingestion of contaminated food. Marine species of Brucella have been recognized lately and there are reports of human infections with these species, demonstrating the wide range and adaptability of these bacteria.

\section{REFERENCES}

[1] Lucero NE, Ayala SM, Escobar GI, et al. Brucella isolated in humans and animals in Latin America from 1968 to 2008. Epidemiol Infect 2008; 136: 496-503.

[2] Nicoletti P. The epidemiology of bovine brucellosis. Adv Vet Sci Comp Med 1980; 24: 69-98.

[3] Verger JM, Garin-Bastuji B, Grayon M, et al. La brucellose bovine à B. melitensis en France. Ann Rech Vét 1989; 20: 93-102.

[4] Dafni I, Hoyda G, Feinhaken D, et al. Observations on $B$. melitensis infection in israeli cattle herds. Israel J Vet Med 1991; 46: 13-9.

[5] Manthei CA. Brucellosis in cattle. In: Brucellosis, a symposium. Washington, D.C. Am Ass Adv Sci 1950; p. 172-87.

[6] Crawford RP, Adams LG, Williams JD. Relationship of fetal age at conjunctival exposure of pregnant heifers and B. abortus isolation. Am J Vet Res 1987; 48: 755-7.

[7] Carpenter CM. Bacterium abortus invasion of the tissues of calves from the ingestion of infected milk. Cornell Vet 1924; 14: 16-31.

[8] Bang B. Infectious abortion in cattle. J Comp Pathol Ther 1906; 19: 191-202.

[9] Thomsen A. Experimental studies on the incubation period of infectious abortion in cattle. Br Vet J 1950; 106: 41-5.

[10] Fitch CP, Boyd WL, Bishop LM, et al. Localization of B. abortus in the bovine uterus. Cornell Vet 1939; 22: 253-60.

[11] Acha, NP, Szyfres B. Zoonoses and Communicable diseases common to man and animals, $3^{\text {rd }}$ ed. Pan American Health Organization (PAHO): Washington D.C. 2003; vol. 1.

[12] Emminger AC, Schalm OW. The effect of Brucella abortus on the bovine udder and its secretion. Am J Vet Res 1943; 4: 100-9.

[13] Schlafer DH, Miler RB. Female genital system. In: Maxie MG, Ed. Pathology of domestic animals. $5^{\text {th }}$ ed. Elsevier Saunders: Philadelphia 2007; vol. 3: pp. 484-9.

[14] Xavier MN, Paixão TA, Poester FP, et al. Pathological, immunohistochemical and bacteriological study of tissues and milk of cows and fetuses experimentally infected with Brucella abortus. J Comp Pathol 2009; 140: 149-57.

[15] Harmon BG, Adams LG, Frey M. Survival of rough and smooth strains of Brucella abortus in bovine mammary gland macrophages. Am J Vet Res 1988; 49: 1092-7. 
[16] Wilesmith JW. The persistence of Brucella abortus infection in calves: A retrospective study of heavily infected herds. Vet Rec 1978; 103: 149-53.

[17] Edgington BH, Donham CR. Infection and reinfection experiments with Bang's disease. J Agric Res 1939; 59: 609-18.

[18] Schroeder EC, Cotton WE. Some facts about abortion disease. J Agric Res 1917; 9: 9-16.

[19] Buck JM, Creech TT, Ladson HH. Bacterium abortus infection of bulls. J Agric Res 1919; 17: 239-46.

[20] Foster RA, Ladds PW. Male genital system. In: Maxie MG, Ed. Pathology of Domestic Animals. $5^{\text {th }}$ ed. Elsevier Saunders: Philadelphia 2007; vol. 3, pp. 565-619.

[21] Lambert G, Manthei CA, Deyoe BL. Studies on B. abortus infection in bulls. Am J Vet Res 1963; 24: 1152-7.

[22] Plant JW, Claxton PD, Jakovljevic D, et al. B. abortus infection in the bull. Aust Vet J 1976; 52: 17-20.

[23] Lambert G, Deyoe BL, Painter GM. Postvaccinal persistence of $B$. abortus strains 19 in two bulls. J Am Vet Med Ass 1964; 145: 90911.

[24] Danks AG. B. abortus strain 19 orchitis in a bull. Cornell Vet J 1943; 33: 381-2.

[25] Lubbehusen RE, Fitch CP. A report of experimental work on the bull as a factor in the spread of infectious abortion. J Am Vet Med Ass 1926; 68: 467-81.

[26] Fensterbank R. Congenital brucellosis in cattle associated with localisation in a hygroma. Vet Rec 1978; 103: 283-4.

[27] Bracewell CD, Corbel MJ. An association between arthritis and persistent serological reactions to B. abortus in cattle from apparently brucellosis-free herds. Vet Rec 1980; 106: 99-101.

[28] Smith T. Pneumonia associated with Bacillus abortus (Bang) in fetuses and new-born calves. J Exp Med 1925; 41: 639-48.

[29] López A, Hitos F, Pérez A, et al. Lung lesions in bovine fetuses aborted by B. abortus. Can J Comp Med 1984; 48: 275-7.

[30] Deyoe BL. Brucellosis. In: Leman AD, Straw B, Glock RD, et al., Eds. Diseases of swine. $6^{\text {th }}$ ed. Ames: Iowa State University Press 1986; pp. 599-607.

[31] Gillespie JH, Timoney JF. Hagan and Bruner's infectious diseases of domestic animals. Cornell University Press: Ithaca, NY 1981; p. 85.

[32] Luchsinger DW, Anderson RK. Longitudinal studies of naturally acquired Brucella abortus infection in sheep. Am J Vet Res 1979; 40: 1307-12.

[33] Paolicchi FA, Terzolo HR, Campero CM. Isolation of Brucella suis from the semen of a ram. Vet Rec 1993; 132: 67

[34] Alton GG. The epidemiology of B. melitensis infection in sheep and goats:187-196. B. melitensis. In: Verger JM, Plommet M, Eds. Martinus Nijhoff Publishers: The Netherlands 1985.

[35] FAO/OMS. Comité Mixto de Expertos en Brucelosis. Sexto Informe. Organización Mundial de la Salud, Ginebra: Suiza 1986; p. 149.

[36] Haughey KG, Hughes KL, Hartley WJ. ovis infection. 2. The infection status in breeding flocks as measured by examination of rams and the perinatal lamb mortality. Aust Vet J 1968; 44: 531-5.

[37] Alton GG. B. melitensis. Animal Brucellosis. In: Nielsen \& Duncan, Eds. CRC Press: Boca Raton Florida, USA 1990; vol. 17: pp. 383-409.

[38] Leon CF. Brucelosis ovina y caprina. Ed. Office International dês Epizooties - OIE. Paris: Francia 1994; p. 451.

[39] European Commision. Brucellosis in sheep and goats ( $B$. melitensis). Scientific Committee on Animal Health and Animal Welfare - SANCO.C.2/AH/R23/2001, 2001; p. 89.

[40] Robles CA. Salud reproductiva del carnero. INTA. $1^{\text {ra }}$ ed. Bariloche: Argentina 2004; p. 40.

[41] Mikolon AB, Gardner IA, Hernandez de Anda J, et al. Risk factors for brucellosis seropositivity of goats herds in the Mexicali Valley of Baja California, Mexico. Prev Vet Med 1998; 37: 185-95.

[42] FAO/OIE/WHO. Animal health Yearbook. Animal production and health series. FAO: Rome, Italy 1997.

[43] Enright FM. The pathogenesis and pathobiology of infection in domestic animals. Animal brucellosis. In: Nielsen \& Duncan, Eds. CRC Press, Boca Ratón: Florida, USA 1990; pp. 301-320.

[44] Jubb KVF, Kennedy PC, Palmer N. Pathology of domestic animals. $4^{\text {th }}$ ed. Academic Press: San Diego, California, USA 1993; vol. 3: p. 653.

[45] Grilló MJ, Barberán M, Blasco JM. Transmission of B. melitensis from sheep to lambs. Vet Rec 1997; 140: 602-95.
[46] Blasco JM, Barberán M. Brucelosis ovina: Epidemiología, Patogenia y Cuadro clínico. Brucella ovis. Tratado de Patologia y Produccion ovina. Luzans ediciones: Madrid, España 1990; pp. 2532.

[47] Aldomy FM, Jahans KL, ltarazi YH. Isolation of B. melitensis from aborting ruminants in Jordan. J Comp Pathol 1992; 107: 239-42.

[48] McFarlane D, Salisbury RM, Osborne HG, et al. Investigation into sheep abortion in New Zealand during he 1950 lambing season. Aust Vet J 1952; 28: 221-6.

[49] Kennedy PC, Frazier LM, McGowan B. Epididymitis in rams, Pathology and bacteriology. Cornell Vet 1956; 46: 303-19.

[50] Buckrell BC, McEwen SA, Johnson WH, et al. Epididymitis caused by Brucella ovis in a southern Ontario sheep flock. Can Vet J 1985; 26: 293-6.

[51] Buddle MB. Studies on Brucella ovis (N.SP), a cause of genital disease of sheep in New Zealand and Australia. J Hygiene 1956; 54: 351-64.

[52] Burgess GW, McDonald JW, Norris MJ. Epidemiological studies on ovine brucellosis in selected ram flocks. Aust Vet J 1982; 59: 45-7.

[53] Cedro VC, Cisale HO, De Benedetti L. Brucelosis genital ovina. Epididimitis del carnero. Rev Inv Ganad 1963; 16: 12-8.

[54] De Wet JAL, Erasmus JA. Epididymitis of rams in the central and southern districts of the Orange Free State. J S Afr Vet Ass 1984; 55: 173-9.

[55] Haughey KG, Hughes KL, Hartley WJ. Brucella ovis infection. 2. The infection status in breeding flocks as measured by examination of rams and the perinatal lamb mortality. Aust Vet J 1968; 44: 531 5.

[56] Jansen BC. The aetiology of ram epididymitis. Onder J Vet Res 1980; 47: 101-7.

[57] Kennedy PC, Frazier LM, McGowan B. Epididymitis in rams: pathology and bacteriology. Cornell Vet 1956; 46: 303-19.

[58] Moro MS. Brucellosis ovina producida por Brucella ovis. Centro Panamericano de Zoonosis, OPS/WHO. Ramos Mejia: Argentina 1974; p. 39.

[59] Robles CA, La Torraca A, Sancholuz M, et al. Ovine brucellosis in Merino flocks in Chubut province. Vet Arg 1993; 10: 458-61.

[60] Simmons GC, Hall WT. Epididymitis of rams. Aust Vet J 1953; 29: 33-40.

[61] Biberstein EL, McGowan B, Olander H, et al. Epididymitis in rams: Studies on pathogenesis. Cornell Vet 1964; 54: 27-41.

[62] Plant JW, Eamens GJ, Seaman JT. Serological, bacteriological and pathological changes in rams following different routes of exposure to Bucella ovis. Aust Vet J 1986; 63: 409-12.

[63] Webb RF, Quinn CA, Cockram FA, et al. Evaluation of procedures for the diagnosis of Brucella ovis infection in rams. Aust Vet $\mathrm{J}$ 1980; 56: 172-5.

[64] Jones LM, Dubray G, Marly J. Comparison of methods of diagnosis of Brucella ovis infection of rams. Ann Rech Vet 1975; 6: 11-22.

[65] Kott RW, Halver GC, Firehammer B, et al. Relationships between Brucella ovis semen culture and various semen and serology parameters. Theriogenology 1988; 29: 961-70.

[66] Robles CA, Uzal FA, Olaechea FV, et al. Epidemiological observations in a Corriedale flock affected by Brucella ovis. Vet Res Commun 1998; 22: 435-43.

[67] Cameron RD, Lauerman LH. Characteristics of semen changes during $B$. ovis infection in rams. Vet Rec 1976; 99: 231-3.

[68] Bulgin MS. B. ovis excretion in semen of seronegative, clinically normal breeding rams. J Am Vet Med Ass 1990; 196: 313-5.

[69] McGowan B, Shultz G. Epididymitis of rams: Clinical description and field aspects. Cornell Vet 1956; 46: 277-81.

[70] Van Tonder EM. Examination of rams for genital soundness. J S Af Vet Med Ass 1977; 48: 267-72.

[71] Jansen BC. The aetiology of ram epididymitis. Onderstepoort J Vet Res 1980; 47: 101-7.

[72] Lozano EA. Etiologic significance of bacterial isolates from rams with palpable epididymitis. Am J Vet Res 1986; 47: 1153-6.

[73] Robles CA, Urcullú JA, Uzal FA. Primer diagnóstico en Patagonia de orquioepididimitis en carneros por Bacilos Pleomórficos Gram negativos. Vet Argent 1990; 7: 453-5.

[74] Cyetnic Z, Spicic S, Curic S, et al. Isolation of B. suis biovar 3 from horses in Croatia. Vet Rec 2005; 156: 584-5. 
[75] Millan MAP, Baskerville A, Ambleton P, et al. Experimental $B$. abortus infection in the horse: observations during the three months following inoculation. Res Vet Sci 1982; 33: 351-9.

[76] Millan MAP, Cockrem DS. Observations of the long term effects of $B$. abortus infection in the horse, including effects during pregnancy and lactation. Equine Vet J 1986; 18: 388-90.

[77] Carter GR, Davis E. Microbial diseases. In: Carter GR, Payne PA, Davis E, Eds. A Guide to the Microbial and Parasitic Disease of Horses. [on line] (2007). www.ivis.org [consulted on 4 september 2009].

[78] Carrigan MJ, Cockram FA, Nash GV. B. abortus biotype 1 arthritis in a horse. Aust Vet J 1987; 64: 190.

[79] Ocholi RA, Bertu WJ, Kwaga JKP, et al. Carpal bursitis associated with B. abortus in a horse in Nigeria. Vet Rec 2004; 155: 566-7.

[80] CFSPH. Canine Brucellosis: B. canis. Animal Disease Factsheets [on line] (2007).www.ivis.org [ consulted on 7 august 2009]

[81] Megid J, Brito AF, Moraes CCG, et al. Epidemiological assessment of canine brucellosis. Arq Bras Med Vet 1999; 51: 43940.

[82] Shin S, Carmichael LE. Canine Brucellosis caused by B. canis. Recent Advances in Canine Infectious Diseases. [on line] (1999). www.ivis.org [consulted on 7 august 2009].

[83] Hollett RB. Canine brucellosis: Outbreaks and compliance. Theriogenology 2006; 66: 575-87.

[84] Carmichael LE, Kenney RM. Canine abortion caused by B. canis. J Am Vet Med Assoc 1968; 152: 605-16.

[85] Johnson CA, Walker RD. Clinical signs and diagnosis of B. canis infection. Comp Cont Educ Pract Vet 1992; 14: 763-72.

[86] Keid LB, Soares RM, Morais ZM, et al. Brucella spp. Isolation from dogs from commercial breeding kennels in São Paulo State, Brazil. Braz J Microbiol 2004; 35: 161-6.

[87] Wanke MM. Canine brucellosis. Anim Reprod Sci 2004; 82-83: 195-207.

[88] Brennan SJ, Ngeleka M, Philibert HM, et al. Canine brucellosis in a Saskatchewan kennel. Can Vet J 2008; 49: 703-8.

[89] Smeak DD, Olmstead ML, Hohn RB. B. canis osteomyelitis in two dogs with total hip replacements. J Am Vet Assoc 1987; 191: 98690.

[90] Vinayak A, Greene CE, Moore PA, et al. Clinical resolution of $B$. canis-induced ocular inflammation in a dog. J Am Vet Med Assoc 2004; 224: 1804-7.

[91] Anderson GI, Binnington AG. Discospondylitis and orchitis associated to high titre in a dog. Can Vet J 1983; 24: 249-52.

[92] Ledbetter EC, Landry MP, Stokol T, et al. B. canis endophtalmitis in 3 dogs: clinical features, diagnosis and treatment. Vet Ophtalmol 2009; 12: 183-91.
[93] Wanke MM, Baldi PC, Loza ME, et al. Canine brucellosis in Argentina: a retrospective study of 371 suspected cases. In: England G, Concannon P, Schafer-Somi, Eds. Abstracts of the $6^{\text {th }}$ International Symposium on Canine and Feline Reproduction. University of Veterinary Sciences, Viena, Austria, 2008. [on line]. www.ivis.org [consulted on 7 august 2009]

[94] Baek BK, Lim MS, Rahman MS, et al. B. abortus infection in indigenous Korean dogs. Can J Vet Res 2003; 67: 312-4.

[95] Megid J, Salgado VR, Keid LB, et al. Infecção em cão por $B$. abortus: relato de caso. Arq Bras Med Vet Zootec 2007; 59: 15835.

[96] Forbes LB. B. abortus infection in 14 farm dogs. J Am Vet Med Assoc 1190; 196: 911-6.

[97] Neiland KA, Miller LG. Experimental B. suis type 4 infections in domestic and wild Alaskan carnivores. J Wild Dis 1981; 17: 183-9.

[98] Barr SC, Eilts BE, Roy AF, et al. Brucella suis biotype 1 infection in a dog. J Am Vet Med Assoc 1986; 189: 686-7.

[99] Mantur BG, Amarnath SK, Shinde RS. Review of clinical and laboratory fetures of human brucellosis. Ind J Med Microbiol 2007; 25: $188-202$.

[100] Seleem MN, Boyle SM, Sriranganathan N. Brucellosis: a reemerging zoonosis. Vet Microb 2009; (in press), doi.org/10.1016/j.vetmic.2009.06.021.

[101] Kyebambe PS. Acute meningomyeloencephalo-spondylosis in a teenage male. Afr Health Sci 2005; 5: 69-72.

[102] Tikare NV, Mantur BG, Bidari LH. Brucelar meningitis in an infant - evidence for human breast milk transmission. J Trop Pediatr 2008; 54: 272-4.

[103] Godfroid J, Cloeckaert A, Liautard JP, et al. From the discovery of the Malta fever's agent to the discovery of a marine mammal reservoir, brucellosis has continuously been a re-emerging zoonosis. Vet Res 2005; 36: 313-26.

[104] Starakis I, Polyzogopoulou E, Siagris D, et al. Unusual manifestation of brucellosis: liver abscess and pancytopenia caused by Brucella melitensis. Eur J Gastroenterol Hepatol 2008; 20: 34952.

[105] Papaionnides D, Korantzopoulos P, Sinapidis D, et al. Acute pancreatitis associated with brucellosis. J Pancreas 2006; 7: 62-5.

[106] Schoenemann J, Lütticken R, Scheibner E. B. canis infection in man. Dtsch Med Wochenschr 1986; 3: 20-2.

[107] Rousseau P. B. canis infection in a woman with fever of unknown origin. Postgrad Med 1985; 78: 253-4.

[108] Lucero NE, Jacob NO, Ayala SM, et al. Unusual clinical presentation of brucellosis caused by B. canis. J Med Microbiol 2005; 54: 505-8. 